Phinisi Integration Review
Vol. 4, No.1, Februari 2021 Hal 84-92
Website: http://ojs.unm.ac.id/pir
p-ISSN: 2614-2325 dan e-ISSN: 2614-2317
DOI: https://doi.org/10.26858/pir.v4i1.19354

\title{
Peran Ganda Perempuan Pekerja Rumput Laut dalam Keluarga di Kabupaten Bantaeng
}

\author{
Irwan $^{1}$, Hasruddin Nur ${ }^{2}$ \\ Universitas Sawerigading Makassar, Indonesia \\ Email : irwanunsa212@gmail.com
}

\begin{abstract}
Research objectives: 1. To determine the dual role of women seaweed farmers in the family of seaweed farmers in Pa'jukang sub-district, Bantaeng Regency, 2. To find out how the dual roles of women seaweed farmers in the family of seaweed farmers in managing the house (domestic sector) and carry out their roles outside the home (public sector) 3. To determine the positive and negative impacts of the dual role of women seaweed farmers in the family. The type of research used is descriptive qualitative, through data collection techniques in the form of observation, interviews, and documentation. By using data analysis techniques in the form of data reduction, data presentation, and conclusion. The activity plan in realizing the goals to be achieved, this research is planned to take place from September to December 2020 with the following stages: 1. The researcher conducted a survey in the Pajukakang sub-district, Bantaeng Regency, 2. The researcher prepared the materials used to retrieve the data- data related to research objectives, both secondary data and primary data, 3. Direct researchers to take data using a list of questions for informants, 4. Researchers inventory the problem of women's dual role in the seaweed farming community, and 5. The results of the data obtained processed and analyzed, in order to find the dual role of women lauat farmers, managing time in managing the domestic and public sectors, and the positive and negative impacts of the dual roles of women seaweed farmers.
\end{abstract}

Keywords: Gender, Multiple Roles, Seaweed Farmers

\begin{abstract}
Abstrak. Tujuan penelitian : 1. Untuk mengetahui peran ganda perempuan petani rumput laut dalam keluarga petani rumput laut di kecamatan Pa'jukang Kabupaten Bantaeng, 2. Untuk mengetahui bagaimana peran ganda perempuan petani rumput laut dalam kelaurga petani rumput laut dalam menguurus rumah (sektor domestik) dan melaksanakan perannya di luar rumah (sektor publik) 3. Untuk mengetahui dampak positif dan negatif dari peran ganda perempuan petani rumput laut dalam keluarga. Jenis penelitian yang digunakan bersifat kualitatif deskriftif, melalui teknik pengambilan data berupa observasi, wawancara, dan dokumentasi. Dengan menggunakan teknik analisis data berupa reduksi data, penyajian data, dan pengambilan kesimpulan. Rencana kegiatan dalam mewujudkan tujuan yang ingin dicapai, maka penelitian ini direncanakan berlangsung mulai bulan september sampai bulan desember 2020 dengan tahapan sebagai berikut : 1. Peneliti melakukan survey di kecamatan Pa'jukakang Kabupaten Bantaeng, 2. Peneliti mempersiapkan bahan yang digunakan untuk mengambil data-data yang berkaitan dengan sasaran penelitian, baik data sekunder dan data primer, 3. Peneliti langsung kelapangan untuk mengambil data dengan menggunakan daftar pertanyaan untuk informan, 4. Peneliti mengimventaris permasalahan peran ganda perempuan pada masyarakat petani rumput laut, dan

5. Hasil data yang didapat diolah dan dianalisis, sehingga ditemukan peran ganda perempuan petani rumput lauat, mengatur waktu dalam mengurus sektor domestik dan
\end{abstract}


sektor publik, dan dampak positif dan negatif peran ganda perempuan petani rumput laut.

Kata Kunci : Gender, Peran Ganda, Petani Rumput Laut

Ini adalah artikel dengan akses terbuka dibawah licenci CC BY-NC-4.0

(https://creativecommons.org/licenses/by-nc/4.0/).

\section{PENDAHULUAN}

Di zaman yang semakin berkembang ini, perempuan semakin leluasa untuk aktif dalam berbagai bidang kehidupan, perempuan yang dulu hanya berperan dalam keluarga saja kini banyak yang berada di dunia kerja untuk mencari nafkah. Perempuan yang memiliki dua peran sekaligus yaitu sebagai ibu rumah tangga dan pekerja dapat disebut memiliki peran ganda, peran ganda perempuan bukan lagi hal yang asing hal ini merupakan bukti keberhasilan seorang perempuan.

Peran ganda perempuan menunjukkan bahwa selain berperan disektor domestik perempuan mampu berperan disektor publik dengan bekerja. Sebagai warga negara, perempuan dan laki-laki memiliki kesempatan dan peran yang sama untuk berkembang di berbagai bidang kehidupan. Biasanya tulung punggung keluarga adalah suami namun sekarang banyak perempuan yang berperan aktif dalam mendukung ekonomi keluarga, perempuan turut berusaha untuk meningkatkan kesejahteraan keluarga dengan pekerja sebagai pekerja rumput laut, perempuan dapat membantu untuk mencukupi kebutuhan keluarga, perempuan merasa kebutuhan keluarga tidak cukup terpenuhi hanya dengan mengandalkan penghasilan suami saja oleh karena itu perempuan merasa harus bekerja agar memiliki penghasilan untuk membantu mencukupi kebutuhan keluarga.

Peran ganda perempuan memberikan konsekuensi yang berat untuk perempuan, disatu sisi perempuan harus bertanggung jawab atas pekerjaannya namun disisi lain harus bertanggung jawab dalam keluarganya terutama pada suami dan anak. Perempuan yang aktif dalam pekerja sulit untuk menjalankan perannya dalam keluarga, perempuan pekerja kurang memiliki waktu untuk mengasuh, merawat, dan mendidik anak mereka karena waktu yang dimiliki harus dibagi dengan pekerjaan, perempuan pekerja terkadang harus menitipkan anak mereka kepada keluarga karena harus bekerja untuk mencukupi kebutuhan hidup sehari-hari.

$$
\text { Keluarga merupakan kesatuan }
$$
masyarakat yang terkecil, yang terdiri dari ayah, ibu dan anak-anaknya. Pada umumnya sebuah keluarga tersusun dari orang orang yang saling berhubungan darah atau perkawinan meskipun tidak selalu saling berbagi atap (rumah), meja makan, makanan, uang, bahkan emosi dapat menjadi faktor untuk mendefinisikan sekelompok orang sebagai suatu keluarga (Azis : 2006)

Perilaku yang dilakukan oleh suami istri dengan tujuan untuk membentuk keluarga yang bahagia, kekal dan sejahtera dipandang sebagai perilaku kekeluargaan, ini juga dapat diartikan sebagai perilaku dalam kehidupan bersama yang didasari semangat saling pengertian, kebersamaan rela berkorban, saling asah, asih, dan asuh serta tidak ada maksud untuk menguntungkan diri pribadi dan merugikan anggota lain dalam keluarga tersebut. Seorang laki-laki sebagai ayah maupun perempuan sebagai ibu di dalam suatu keluarga memiliki kewajiban bersama untuk berkorban guna kepentingan bersama. Kedudukan ayah ataupun ibu di dalam keluarga memiliki hak yang sama untuk ikut melakukan kekuasaan demi keselamatan, kebahagiaan, dan kesejahteraan seluruh anggota. Status suami istri dalam keluarga adalah sama lainnya, maksudnya masing-masing dianggap baik dalam bertindak. Suatu keluarga akan kokoh dan berwibawa apabila dari masing-masing anggota keluarga yang ada di dalamnya selaras, serasi dan seimbang. Secara badaniah, perempuan berbeda dengan laki-laki. Alat kelamin perempuan berbeda dengan alat kelamin laki-laki, suara perempuan lebih halus, perempuan melahirkan anak dan sebagainya. 
Irwan, Nur. Peran Ganda Perempuan Pekerja Rumput Laut ...

Selain itu secara psikologis, laki- laki akan lebih rasional, lebih aktif, lebih agresif. Sedangkan secara psikologis perempuan lebih emosional dan lebih pasif (Budiman : 1982).

Orang tua ideal masa mendatang merupakan produk orang tua ideal masa kini. Kalau pada masa kini sudah mulai tampak gejala-gejala negatif yang mempengaruhi pola yang negatif itu bukanlah dengan cara mengagung agungkan masa lampau yang sudah lewat, akan tetapi dengan cara menunjukkan bahwa pola yang berlaku dewasa ini tidak akan menguntungkan manusia pada masa mendatang. Orang tua ideal masa mendatang, seyogyanya mulai dipikirkan dan di coba pada masa kini dalam bentuk usaha untuk lebih menyerasikan nilai spiritualisme dengan nilai materialisme secara proposional.

Yang menjadi tujuan kuhusus dari penelitian ini adalah sebagai berikut : 1 . Untuk mengetahui Peran ganda Perempuan petani rumput laut di kecamatan Pa'jukang kabupaten Bantaeng, 2. Untuk mengetahui bagaimana perempuan petani rumput laut mengatur waktu dalam mengurus rumah (sektor domestik) dan melaksanakan perannya diluar rumah (sektor publik). 3. Untuk mengetahui dampak positif dan negatif dari peran ganda perempuan petani rumput laut dalam keluarga.

\section{METODE}

Untuk mengetahui penelitian ini dimulai dari mana, maka dalam pembahasan berikut ini penulis akan mengetangahkan bagian alur penelitian ini, maka peneliti mengemukakan apa yang dilakukan pada tahap-tahap berikut : Peneliti melakukan survey di kecamatan Pa'jukakang Kabupaten Bantaeng, Peneliti mempersiapkan bahan yang digunakan untuk mengambil data-data yang berkaitan dengan sasaran penelitian, baik data sekunder dan data primer, Peneliti langsung kelapangan untuk mengambil data dengan menggunakan daftar pertanyaan untuk informan, Peneliti mengimventaris permasalahan peran ganda perempuan pada masyarakat petani rumput laut, Hasil data yang didapat diolah dan dianalisis, sehingga ditemukan peran ganda perempuan petani rumput lauat, mengatur waktu dalam mengurus sektor domestik dan sektor publik, dan dampak positif dan negatif peran ganda perempuan petani rumput laut.

\section{HASIL DAN PEMBAHASAN}

\section{Peran Ganda Perempuan Pekerja Rumput Laut dalam Keluarga di Kecamatan Pa'jukukang Kabupaten Bantaeng}

Perempuan merupakan sebuah kekuatan dalam keluarga karena dengan tangan merekalah keluarga bisa menjadi keluarga yang baik. Perempuan mampu memberikan sebuah kontribusi yang sangat luar biasa dalam kehidupan mereka karena mampu menutupi kesedihan mereka. Perempuan adalah makhluk yang sangat rapuh namun mereka mampu bangkit dalam kehidupan mereka karena hal yang mereka fikirkan adalah bagaimana mereka bisa menghidupi keluarga. Didalam kehidupan sehari-hari perempuan bukanlah makhluk yang rapuh melainkan perempuan adalah makhluk yang sangat kuat karena mereka bisa melakukan yang terbaik buat keluarga mereka.

Peran ganda perempuan pekerja rumput laut dalam keluarga sangatlah penting karena melihat tugas yang harus dilaksanakan mulai dari pagi sampai malam tak lepas dari tanggung jawab yang tidak bisa dihindari pengaturan atau pengelolaan rumah tangga yang tidak mengenal waktu tersebut berkaitan dengan mengasuh, mendidik, menjaga dan mengarahkan anakanak terutama bagi yang belum dewasa. Mengurus membereskan rumah termasuk perabot rumah dan menjaga kebersihan serta kerapian pakian seluruh anggota keluarga.

Manusia adalah makhluk sosial yang saling membutuhkan satu sama lainnya sehingga manusia harus saling bergantung satu sama lainnya, perempuan banyak dikategorikan sebagai makhluk Tuhan yang paling lemah namun kenyataannya perempuan mampu berdiri sendiri untuk melakukan segala hal yang di lakukan seorang laki-laki. Seperti yang diungkapkan oleh informan Raudatul Jannah yang mengatakan bahwa:

"iya lulusan SMA, anak ke 5 dari 8 bersaudara, karena masalah ekonomi yang tidak bercukupan sehingga tidak mampu untuk melanjutkan ke jenjang perguruan tinggi, hanya inilah pekerjaan saya setiap hari dengan rumput laut untuk memenuhi kebutuhan setiap hari".

Wawancara diatas menjelaskan bahwa karena masalah ekonomi yang 
tidak bercukupan saja, sehingga tidak mampu untuk melanjutkan kejenjang perguruan tinggi.

Di kecamatan Pa'jukukang perempuan-perempuan sangat berperan dalam mencari nafkah yaitu dengan bekerja sebagai pekerja rumput laut. Perempuan sebagai pencari nafkah tersebut memiliki berbagai latar belakang sebagian masih memiliki suami dan sebagian belum menikah. Banyak perempuan sebagai pencari nafkah dalam keluarga yang sudah memiliki suami dan harus bekerja untuk kebutuhan hidup.

\section{Perempuan Pekerja Rumput Laut Mengatur Waktu dalam Mengurus Rumah (Sektor Domestik) dan Melaksanakan Perannya diluar Rumah (Sektor Publik)}

a. Peran ganda perempuan pekerja penjual ikan disektor domestik

Perempua pekerja rumput laut mengatur waktu dalam mengurus rumah atau di sektor domestik adalah pekerja yang dilakukan terkait dengan pemeliharaan rumah tangga. Pekerjaan ini meliputi penyediaan makanan atau memasak, menjaga kebersihan rumah seperti mencuci, menyapu, mengepel serta merawat anakanak, orang sakit dan orang yang sudah tua. Pekerjaan ini paling umum di lakukan oleh perempuan.

Selanjutnya wawancara dengan ibu Aminah yang mengatakan bahwa:

$$
\text { "saya mengatur waktu dalam }
$$
mengurus rumah tangga, dimana saya harus membagi waktu mengurus suami dan anak, menyiapkan makanan, membereskan rumah dan sisi lain saya sebagi pekerja rumput laut dari pagi bahkan sampai malam."

Wawancara di atas menjelaskan bahwa ibu Aminah membagi waktu mengurus suami dan anaknya, dan sisi lain ibu Aminah pekerja rumput laut dari pagi bahkan sampai malam.

Waktu yang diperlukan dalam kegitan domestik adalah lebih dari 10 jam dengan waktu tersebut dapat melakukan aktivitas seperti memasak, mencuci, mengurus anak dan mengurus rumah tangga. Perempuan harus belajar untuk dapat menyelesaikan setiap pekerjaan dengan cepat walaupun seringkali mengorbankan kegiatan publik untuk dapat menyelesaikan kegiatan domestik yaitu mengurus rumah tangga. Perempuan juga merupakan penggerak dalam keluarga, karena tanpa perempuan akan susah menangani masalah kebutuhan dalam keluarga tanggung jawab besar yang membutuhkan kesabaran sehingga menjadi pribadi yang dapat diandalkan dan membuat perempuan harus bisa memanajemen waktu dengan baik.

\section{b. Peran ganda perempuan pekerja rumput laut di sektor publik}

Perempuan yang bekerja di sektor publik yaitu perempuan yang bekerja sebagai pekerja rumput laut memiliki dampak positif terhadap keluarganya. Dengan bekerjanya perempuan sebagai pekerja rumput laut dapat membantu ekonomi rumah tangganya seperti dapat membantu biaya pendidikan anaknya, membantu biaya kehidupan sehari- hari dan juga meningkatkan status keluarganya.

Peran produktif yang sering di sebut dengan peran di sektor publik yang di lakukan perempuan terdapat di sektor formal atau informal. Sektor formal adalah sektor dimana pekerjaan didasarkan atas kontrak kerja yang jelas dan pengupahan diberikan secara tetap atau kurang lebih permanen. Pekerja sektor formal dapat digolongkan terampil dan pendidikan, sedangkan sektor informal tidak terampil dan tidak berpendidikan.

Pada masyarakat Kecamatan Pa'jukukang, peran perempuan mengalami perubahan sebagai reaksi atas perubahan struktur perekonomian yang mengarah pada proses industrialisasi. Perempuan pekerja di sektor formal cenderung memiliki tingkat pendidikan dan keterampilan, produktivitas tenaga kerja serta tingkat upah yang juga relative lebih tinggi dibandingkan dengan perempuan pekerja disektor informal.

Perempuan pekerja rumput laut disektor publik umumnya sudah memperoleh pendidikan yang cenderung tinggi. Perempuan ingin merealisasikan pendidikan yang diterimanya dalam hal bekerja. Dalam masa pendidikan perempuan memperoleh ilmu dari pendidikan yang dijalaninya. Perempuan mengaplikasikan 
Irwan, Nur. Peran Ganda Perempuan Pekerja Rumput Laut ...

ilmu tersebut dengan bekerja. Bekerja merupakan sebuah pencapaian untuk dapat meningkatkan taraf hidup manusia.

Karena itu, meskipun wanita diperbolehkan untuk bekerja disektor publik, dia tidak juga meninggalkan sektor domestik seperti pengasuhan anak-anaknya, sebab anak- anak ini adalah tanggung jawab suami dan istri. Seperti yang di katakan Ibu Yati yang mengatakan bahwa:

"sebagai perempuan kita harus perpandai mengatur waktu dalam mengurus rumah tangga dan mengatur waktu diluar rumah pada saat kerja rumput laut."

Wawancara diatas menjelaskan bahwa sebagai perempuan kita harus perpandai mengatur waktu baik didalam rumah maupun diluar rumah dalam mengurus rumah tangga.

Selain dari beberapa kegiatan yang dilakukan perempuan pekerja rumput laut di atas, menjemur rumput laut adalah salah satu kegiatan rutinitas yang dilakukan perempuan pekerja rumput laut di Kecamatan Pa'jukang Kabupaten Bantaeng menjemur rumput laut ini adalah kegiatan untuk membuat rumput laut kering.

Kegiatan utama perempuan pekerja rumput laut sangat berarti dalam membantu untuk memenuhi kebutuhan setiap hari, perempuan berperan dalam mencari tambahan penghasilan untuk memenuhi kebutuhan keluarga, peran perempuan dalam mencari nafkah dimulai saat ada pemasukan rumput laut disitulah perempuan terlibat dalam penjualan rumput laut.

Kecamatan Pa'jukang Kabupaten Bantaeng perempuan mempunyai peran yang berarti hingga terjualnya rumput laut sebagian kecil perempuan ini adalah istri dari nelayan mereka mempunyai tanggung jawab untuk menjual rumput laut di pedagang. Para perempuan yang sebagian kecil istri nelayan menunggu perahu suaminya ditempat setelah itu para perempuan bersiap-siap untuk menjemur rumput laut.

Bagi masyarakat Pa'jukakang perempuan pekerja rumput laut dan memiliki anak, persepsi diri untuk menjadi seorang perempuan yang baik dan juga sukses dikarirnya menjadi suatu polemik yang harus dihadapi. Tantangan perempuan dalam melakukan tugasnya banyak yang bersumber dari dirinya sendiri, dalam membina diri untuk menjadi pribadi yang mantap, pribadi yang mantap antara lain yaitu:

Melakukan tugas dalam rumah tangga dengan baik.

1. Mengembangkan kemampuan dalam mengatasi

2. Berbuat baik terhadap sesama manusia.

3. Tuluslah dalam bersahabat antara sesama perempuan

5. Terimalah keadaan diri kita apa adanya, sementara itu terus meningkatkan kualitas diri.

\section{B. Dampak Positif dan Negatif dari Peran Ganda Perempuan Pekerja Rumput Laut dalam Keluarga}

Peran ganda yang ditanggung oleh perempuan pekerja rumput laut yaitu menjadi pekerja yang harus dijalankan dalam kehidupan sehari-harinya membuat mereka melaksanakan aktivitasnya. Aktivitas tersebut memberikan dampak positif dan negatif bagi diri mereka dan juga keluarga. Aktivitas peran perempuan pekerja adalah aktivitas harian yang harus dilakukan oleh seorang perempuan, baik itu perempuan yang belum menikah maupun perempuan yang sudah menikah. Bagi perempuan pekerja kegiatan tersebut biasanya dilakukan sebelum mereka berangkat bekerja dan setelah mereka pulang kerja.

Berdasarkan hasil wawancara yang dilakukan pada peran perempuan pekerja dapat diketahui bahwa dirumah ada pekerja perempuan yang melaksanakan pekerjaan rumah bersama-sama dengan suami dan anaknya, tetapi ada juga pekerja perempuan yang seluruh pekerjaan rumah di tangani sendiri tanpa ada bantuan dari suami ataupun anaknya, sehingga mereka mengalami beban kerja. Yaitu bekerja didalam rumah maupun di luar rumah. Seperti yang disampaikan oleh ibu Mira saat ditemui dirumahnya yang mengatakan bahwa:

"suami saya jatahnya hanya mengatarkan saya ketempat kerja, sebelum berangkat bekerja saya menyelesaikan pekerjaan rumah dulu, makan, kemudian berangkat bekerja, nanti capek pulang kerja masih harus masak, mencuci piring, dan yang mengurus rumah saya sendiri."

Wawancara cara diatas 
menjelaskan bahwa ibu mira adalah tulang punggung keluarga, maksudnya disini adalah ibu mira yang berperan penting mencari nafkah untuk keluarganya dan untuk memenuhi kebutuhan hidup keluarganya.

Selanjutnya wawancara dengan Ibu Dia yang mengatakan bahwa:

Kalau saya dek kerja sendiri dari pagi sampai sore, kalau pulang sekolah anak saya kadang dia bantu saya kerja rumput laut kadang tidak membantunya, kalau suami saya jatahnya dirumah saja kadang suami saya dia yang memasak nasi dan cuci piring jadi kalau saya pulang dari tempat kerja rumput laut pekerjaan rumah sudah beressemua.

Wawancara diatas menjelaskan bahwa keseharian ibu Diah bekerja rumput laut hanyalah sendiri tanpa bantuan seorang suami, pada saat pulang sekolah anaknya kadang membantu kadang tidak membantunya kerja rumput laut.

Perempuan pekerja di Pa'jukukang memiliki peran baik bekerja disektor domestic maupun disektor publik. Oleh karena itu, kedudukan atau status seseorang melaksanakan hak-hak atau kewajibannya didalam rumah maupun diluar rumah. Berikut pemaparan mengenai dampak positif dan negatif dari peran perempuan pekerja dalam keluarga.

\section{a. Dampak Positif}

1. Menambah penghasilan rumah tangga

Perempuan pekerja rumput laut dapat berdampak positif terhadap keluarganya sehingga dapat membantu menambah kebutuhan sehari-hari seperti dapat membantu biaya pendidikan anaknya, dapat membeli perlengkapan dapur seperti cabe, beras dan juga dapat membeli perlengkapan rumahnya seperti TV, kulkas dan peralatan dapur. Tujuan dari perempuan pekerja adalah untuk memperoleh penghasilan yang dapat digunakan untuk menambah pendapatan dalam kebutuhan sehingga meringankan beban suami.

Berdasarkan hasil wawancara diatas menjelaskan bahwa perempuan juga ikut berperan dalam menambah pendapatan keluarga untuk memenuhi kebutuhan sehariharinya. Walaupun sebenarnya yang berkewajiban penuh untuk memenuhi kebutuhan keluarga adalah seorang suami.
Ini menunjukkan adanya kemitrasejajaran antara perempuan dan laki-laki dalam rumah tangga. Perempuan tidak hanya berperan dalam urusan rumah tangga saja, tetapi juga dalam urusan mencari nafkah. Selanjutnya wawancara dengan Ibu Wati yang mengatakan bahwa:

"dari pada diam dirumah dek lebih baik saya bekerja rumput laut, hitung-hitung untuk menambah penghasilan dan lumayan juga untuk makan keseharian. Kalau tidak bekerja rumput laut rugi tidak mendapatkan hasilnya dek."

Berdasarkan hasil wawancara diatas menjelaskan bahwa ibu Wati lebih suka bekerja rumput laut dari pada diam dirumah karena bisa menambah penghasilan untuk kebutuhan keseharian.

2. Meningkatkan status keluarga

Status merupakan yang dapat menunjang harkat dan martabat nama baik seseorang. Bahwa dapat positif terhadap perempuan pekerja rumput laut dapat meningkatkan status keluarganya. Sebelum bekerja rumput laut dimana hidupnya yang dahulu serba kekurangan karena penghasilan suaminya tidak mencukupi untuk memenuhi kebutuhan keluarganya. Dimana orang tidak begitu peduli terhadap keluarganya dengan kondisi ekonomi keluarga yang serba kekurangan seperti buat makan sehari-hari saja dulu tidak cukup dan kadang makan satu kali dalam sehari. Sebelum bekerja rumput laut dimana teman tidak ada yang mau mengajak untuk main arisan, dan juga teman tidak mau meminjamkan dana.

3. Terbangun rasa saling pengertian antar anggota keluarga

Perempuan pekerja lebih banyak menghabiskan waktunya ditempat kerja sehingga waktu untuk bertemu dengan anggota keluarga terbatas, namun hubungan antar anggota keluarga tetap baik. Hal ini karena dalam keluarga terbangun rasa saling pengertian, sehingga hubungan mereka tetap harmonis. Hal ini seperti yang diungkapkan oleh ibu Wati yang mengatakan bahwa: "hubungan dengan keluarga baik-baik saja, karena sama-sama menjaga dan saling pengertian juga."

Berdasarkan hasil wawancara diatas menjelaskan bahwa hubungan antar anggota keluarga tetap harmonis terutama hubungan 
Irwan, Nur. Peran Ganda Perempuan Pekerja Rumput Laut ...

pekerja perempuan. Hal ini karena saling menjaga sehingga rasa saling pengertian.

Kesibukan perempuan dalam sektor publik juga tidak menghalangi perhatian mereka terhadap keluarga terutama anak. Mereka masih memberikan perhatian penuh seperti menyiapkan kebutuhan sekolah anak, menyiapkan sarapan dan membantu anak saat belajar. Seperti yang diungkapkan oleh ibu Yani yang mengatakan bahwa:

"biasa-biasa saja, baik-baik saja, selama ini hubungan anggota keluarga saya tidak ada masalah, semuanya berjalan dengan baik, dan saling melengkapi satu sama lain."

Berdasarkan hasil wawancara diatas menjelaskan bahwa hubungan anggota keluarga ibu yani baik-baik saja, dan saling melengkapi satu sama lain.

\section{b. Dampak Negatif}

Perempuan sebagai pekerja rumput laut tersebut harus menjalankan fungsinya dengan baik. Salah satu fungsi domestik yang harus dijalankan oleh perempuan tersebut adalah mengasuh dan mendidik anak, mengatur rumah tangga dan menjalankan fungsinya didapur.

Akibat lain dari dampak negatif perempuan pekerja rumput laut terhadap peranan domestiknya adalah pekerjaan rumah kurang terurus seperti pekerjaan rumah dikerjakan oleh anak dan suaminya seperti menyapu rumah dan mencuci piring, suami kurang diperhatikan seperti suami membuat air kopi sendiri didalam keluarga seharusnya suami harus diperhatikan seperti membuat kopi dan sarapan pagi seharusnya sudah disiapkan oleh istri dan juga memberikan pelayanan yang bagus oleh suami seperti ketika suami sedang makan seharusnya istri ada dan memberikan pelayanan oleh suami pada saat makan. Adapun dampaknya yaitu:

1. Terjadinya perubahan kapasitas pekerjaan rumah

Pekerjaan rumah merupakan pekerjaan yang menjadi tanggung jawab perempuan dalam keluarga seperti memasak dan mengurus anak. Perempuan pekerja disektor informal yaitu perempuan pekerja sebagai pekerja rumput laut ternyata berdampak negatif terhadap keluarga. Perempuan pekerja rumput laut berangkat bekerja dari pagi sampe sore dan waktu untuk mengerjakan pekerjaan rumahnya tidak banyak karena perempuan itu lebih banyak menghabiskan waktunya di temapt rumput laut dari pada dirumah. Jadi, pekerjaan rumahnya kurang terurus, seperti dulu sebelum bekerja pekerjaan rumah (mencuci piring) dikerjakan pada pagi hari tetapi setelah bekerja, piring yang kotor dicuci setelah pulang kerja. Dimana perempuan itu mengerjakan pekerjaan rumahnya bila ada waktu saja di kerjakannya.

2. Kurangnya perhatian kepada suami dan anak

Suami merupakan kepala keluarga yang harus mencukupi kebutuhan keluarganya. Didalam keluarga seharusnya suami harus lebih memperhatikan keluarganya seperti memberi istri uang untuk kebutuhan sehari-hari, menegur keluarganya jika ada salah karena didalam keluarga suami adalah kepala rumah tangga yang mampu memenuhi kebutuhan ekonomi keluarganya. Perempuan pekerja sebagai pekerja rumput laut ternyata berpengaruh terhadap suaminya, dimana istri tidak memperhatikan suaminya karena ia sibuk dengan pekerjaannya sehingga suami merasa kurang diperhatikan oleh istri. Namun, ada sebagian kecil keluarga perempuan pekerja rumput laut yang tidak sempat untuk menyiapkan sarapan pagi buat suaminya karena sebelum berangkat kerja ia menyiapkan dagangannya. Tetapi ada juga sebagian keluarga perempuan pekeraj rumput laut yang sempat memasak sarapan buat suaminya pada pagi hari.

3. Waktu berkumpul dengan keluarga menjadi terbatas

Curahan waktu yang dimiliki oleh perempuan pekerja banyak dihabiskan untuk bekerja, sehingga waktu perempuan pekerja untuk berkumpul dengan anggota keluarganya sangat berkurang, Terutama dengan suami dan anaknya menjadi terbatas. Apalagi bagi mereka yang sama-sama sibuk bekerja, mereka hanya dapat bertemu di waktu pagi hari sebelum berangkat kerja dan malam hari menjelang tidur.

4. Waktu berkumpul dengan masyarakat terbatas

Peran ganda yang harus dijalankan oleh perempuan pekerja dan sebagai ibu rumah tangga membuat waktu yang mereka miliki terkuras untuk ke dua aktivitas tersebut. Dari jam 08.00-16.00 perempuan pekerja rumput laut pulang dari bekerja mereka masih harus 
menjalankan aktivitasnya dalam rumah tangga, sehingga waktu mereka untuk berkumpul dengan tetangga dan masyarakat sekitar lingkungannya menjadi terbatas.

Dari hasil wawancara diatas menjelaskan bahwa hanya pada waktu tertentu saja bisa berkumpul dengan tetangga. Perempuan pekerja hanya dapat berkumpul dengan tetangga dan masyarakat lainnya hanya pada saat ada kegiatan sosial seperti takziyah, arisan, pengajian dan kegiatan sosial lainnya.

Perempuan yang bekerja lebih banyak menghabiskan waktunya di tempat kerja sehingga waktu untuk bertemu dengan anggota keluarga terbatas. Namun hal ini tidak membuat hubungan mereka menjadi tidak harmonis, tetapi malah memunculkan rasa saling pengertian antara anggota keluarga terutama dengan suami mereka. Keduanya saling saling menyadari peran masing-masing. Seorang laki-laki sebagai suami tetap menyadari perannya sebagai kepala rumah tangga yang harus memberikan nafkah untuk keluarganya. Seorang perempuan yang berperan sebagai seorang istri maupun yang belum menikah tetap menjalankan perannya dengan baik yaitu mengurus rumah walaupun mereka harus bekerja.

\section{SIMPULAN DAN SARAN}

Berdasarkan hasil penelitian yang telah dilakukan penulis mengenai peran perempuan pekerja dalam keluarga di Kecamatan Pa'jukukang Kabupaten Bantaeng, maka penulis dapat mengambil kesimpulan sebagai berikut: (1) Peran perempuan di Kecamatan Pa'jukang Kabupaten Bantaeng sangat berperan penting sebagai pencari nafkah utama bagi keluarga baik perempuan yang sudah menikah maupun perempuan yang belum menikah memiliki peran utama mencari nafkah dalam memenuhi kebutuhan hidup keluarga. Penyebab perempuan-perempuan tersebut berperan sebagai pencari nafkah utama dalam keluarga adalah rendahnya penghasilan suami, tingginya tingkat kebutuhan hidup, besarnya tanggungan biaya pendidikan anak, dan adanya dorongan dalam diri untuk memperoleh kehidupan yang lebih mapan; (2) Perempuan pekerja di Kecamatan Pa'jukang Kabupaten Bantaeng berperan penting dalam mencari nafkah dan berkewajiban membantu pendapatan suami yang masih pas-pasan. Pertama perempuan pekerja dalam lingkup domestik yaitu sebagai perempuan baik yang sudah menikah maupun yang belum menikah perempuan mengurus pekerjaan rumah seperti mencuci, memasak, mengepel, menyiapkan kebutuhan rumah dan melayani suami dengan baik. Kedua perempuan pekerja dalam lingkup publik yaitu, menjemur rumput laut, mengolah bibit rumput laut, membantu biaya kehidupan sehari-hari dan meningkatkan status keluarga; (3) Perempuan di Kecamatan Pa'jukang bekerja sebagai pekerja rumput laut pekerjaan ini juga memberikan dampak positif dan negatif. Pertama dampak positif yaitu menambah penghasilan rumah, dapat meningkatkan status keluarga dan terbangun rasa saling pengertian antar anggota keluarga. Kedua dampak negatif dari perempuan pekerja dalam keluarga yaitu terjadinya perubahan kapasitas pekerjaan rumah, kurang terlaksana dalam keluarga, waktu untuk berkumpul dengan keluarga terbatas, dan waktu untuk berkumpul dengan masyarakat terbatas.

Adapun beberapa saran yang bisa disampaikan oleh penulis diantaranya: (1) Penulis berharap bahwa dari hasil penelitian yang dilakukan, penulis lainnya mempunyai refrensi kemudian dari refrensi tersebut penelitian-penelitian terbaru dan lebih actual; (2) Kepada pembaca, diharapkan agar tidak hanya mengetahui isi dari sebuah karya sastra tapi juga mengetahui makna apa saja yang terkandung didalamnya. Selain itu juga pembaca hendaknya mengerti tentang nilainilai moral agar dapat diamalkan dalam kesehariannya.

\section{DAFTAR RUJUKAN}

Aksa Rismwati. 2011. Perempuan Pekerja : Makssar : UNM

Arief Budiman. 1985. Pembagian Kerja Secara Seksual Sebuah Pembahasan Sosiologis tentang Peran Wanita di dalam Masyarakat : Jakarta : PT. Gramedia

Budhy Munawar Rahman, dkk. 2002. Rekonstruksi Metodologis Wacana Kesetraan Gender dalam Islam : Yogyakarta : Pustaka Pelajar

George Ritzer \& Douglas J. Goodman. 2008. Teori Sosiologi Modrn. Terjemahan 
Irwan, Nur. Peran Ganda Perempuan Pekerja Rumput Laut ...

Alimandan.

Jakarta : Kencana

Julia Cleves Mosse. 1996. Gender dan Pembangunan. Yogyakarta : Pustaka Pelajar Koentjaraningrat. 2009. Pengantar Ilmu Antropologi. Jakarta : Rieneka Cipta

Mansour Fakih. 1996. Analisis Gender dan Transpormasi Sosial. Yogyakarta : Pustaka Pelajar

Mustadjar Musdaliah. 2013. Sosiologi Gender dalam Keluarga Bugis. Makassar : Rayhan Intermedia

Nugroho. 2008. Gender dan Administrasi Pusblik. Yogyakarta : Pustaka Pelajar

Nurlaela Bakri. 2013. Perempuan dan Aktivitas Pemenuhan Ekonomi Keluarga. Makassar : UNM

Nur Syam. 2011. Agama Pelacur Dramaturgi Transendental. Yogyakarta : LkiS Printing 